\title{
Effects of Dobutamine and Terbutaline on the Secretion of Glycoproteins from the Acinar Cells of the Rat Submandibular Gland
}

\author{
Yoshiki IWABUCHI, Chihiro AOKI and Taizo MASUHARA \\ Department of Dental Pharmacology. School of Dentistry at Niigata. \\ The Nippon Dental University. Nigata 95\%. Japan \\ Accepted March 31, 1988
}

\begin{abstract}
The actions of dobutamine (DOB) and terbutaline (TER) on the secretion of marker glycoprotein (GP) from the secretory cells of the glands and secretion of fluid from rat submandibular gland (SMG) were investigated in combination with two antagonists, metoprolol (MET) and $\mathrm{ICl}-118551(\mathrm{ICl})$. The ED50 value of fluid secretion was $8.7 \mathrm{mg} / \mathrm{kg}$ for $D O B$ and $5.9 \mathrm{mg} / \mathrm{kg}$ for TER. MET, administered prior to either agonists at a dose of $40 \mathrm{mg} / \mathrm{kg}$, inhibited the fluid secretion. However, the blocking effects of $\mathrm{ICl}$ were considerably lower than those of MET. The electrophoretic profiles of GP in DOB-evoked saliva were similar to those in TER-evoked saliva, and included two characteristic main bands of GP I (130 KDa) and GP IV (21.5 KDa) from the acinar cells and a minor band of GP III (31 KDa) which originated in the cells of the granular tubules. When MET was administered at a dose of $5 \mathrm{mg} / \mathrm{kg}$ prior to DOB, the intensity of band I decreased, whereas that of band III did not change. These results showed that the SMG of rats contains both $\beta_{1}$ - and $\beta_{2}$-adrenoceptors and that $\beta$-receptors which mediate the secretion of GP from the acinus and fluid from the gland are mainly of the $\beta_{1}$-subtype.
\end{abstract}

It is generally recognized that $\beta$-adrenoceptors can be divided into two subtypes: the $\beta_{1}$-subtype, which mediates cardiac stimulation and lipolysis, and the $\beta_{2}$-subtype, which mediates the relaxation of bronchial and vascular smooth muscle. These subtypes were identified by experiments using a series of sympathomimetic amines $(1,2)$. This classification is supported by results of experiments with agonists of both $\beta_{1}$ - and $\beta_{2}-$ receptors and with their antagonists which have recently been developed. In the rat submandibular gland, the $\beta$-adrenoceptors which mediate secretion of fluid (3-6) and protein (3) and glandular enlargement (7-9) are mainly of the $\beta_{1}$-subtype. which mediates secretion of amylase from the rat parotid gland $(10-13)$.

We reported previously that the species of secreted glycoproteins differ markedly between the acini and granular convoluted tubules of the rat submandibular gland (14). We found that characteristic glycoproteins in the acini are secreted into the saliva after stimulation by the non-specific $\beta$-adrenergic agent isoproterenol (15), as well as after stimulation by the cholinergic agent pilocarpine (16) and by substance $P(17)$. whereas glycoproteins characteristic of the granular convoluted tubules are secreted in response to the $\alpha_{1}$-adrenergic agent, methoxamine (18. 19).

We are interested in assaying the specificity of the action of $\beta_{1}$ and $\beta_{2}$-adrenergic agonists on secretory cells by analysis of the marker giycoproteins contained in the acinus and granular convoluted tubules of the rat submandibular gland. In the present study, we have examined the specificity of the actions of dobutamine, a $\beta_{1}$-agonist, and terbutaline. a $\beta_{2}$-agonist. on the secretion of marker glycoproteins, protein and fluid from the submandibular glands of rats, using metoprolol. a selective $\beta_{1}$-antagonist, and $\mathrm{ICl}$ 118551 , a selective $\beta_{2}$-antagonist. 


\section{Materials and Methods}

Collection of submandibular saliva: Male Sprague-Dawley rats, eight weeks of age. were fasted but given water ad libitum for the 24 hours prior to examination. Each rat was anesthetized with sodium pentobarbital (50 $\mathrm{mg} / \mathrm{kg}$ b. wt., i.p.) and placed on a heating pad maintained at $37^{\circ} \mathrm{C}$. The excretory ducts of the sublingual gland were ligated after being separated from the adherent tissues around the submandibular gland. The trachea was cannulated with a polyethylene tube (MRC, $2 \times 2.7 \mathrm{~mm}$ ). 1) Either dobutamine or terbutaline was administered intraperitoneally in doses which ranged from 5 to $40 \mathrm{mg} / \mathrm{kg} \mathrm{b}$. wt., and submandibular saliva was collected from the tip of the ductal cannula with a capillary micropipette (Drummond Microcaps, 10 and $20 \mu l)$ for periods of 5 min over the course of $30 \mathrm{~min}$. 2) Metoprolol or $\mathrm{ICl}$. 118551 at doses of $0.2,1.0$ and $5.0 \mathrm{mg} / \mathrm{kg} \mathrm{b}$. wt. was injected intravenously $30 \mathrm{~min}$ prior to injection of each agonist at a dose of 40 $\mathrm{mg} / \mathrm{kg} \mathrm{b}$. wt. After the injection of each of the agonists, submandibular saliva was collected as described above. At the end of each experiment, the submandibular glands were carefully removed, and flow rates were then calculated as the volume of fluid elicited per minute per milligram of wet weight of each gland.

Preparation of functional segments: Parenchymal components from the rat submandibular gland were isolated by the method of Masuhara and Iwabuchi (14). Rats were anesthetized with pentobarbital (50 $\mathrm{mg} / \mathrm{kg}$, i.p.), and the submandibular gland was perfused via the carotid artery with a solution of collagenase which consisted of $0.1 \%$ collagenase (Sigma, Type 11 ), $1.0 \mathrm{mM}$ $\mathrm{CaCl}_{2}$ and $0.1 \%$ bovine serum albumin in modified Hanks' medium (137 mM NaCl. $5 \mathrm{mM} \mathrm{KCl}, 0.8 \mathrm{mM} \mathrm{MgSO}_{4}, 0.33 \mathrm{mM}$ $\mathrm{NaH}_{2} \mathrm{PO}_{4}, 0.44 \mathrm{mM} \mathrm{KH}_{2} \mathrm{PO}_{4}, 1 \mathrm{mM} \mathrm{MgCl}$ and $10 \mathrm{mM}$ Tris- $\mathrm{HCl}, \mathrm{pH} 7.4$ ). The submandibular gland was immediately removed, sliced, and then incubated for $120 \mathrm{~min}$ at $37^{\circ} \mathrm{C}$ in an aliquot of the same collagenase solution in an atmosphere of $95 \% \mathrm{O}_{2}$ plus $5 \%$ $\mathrm{CO}_{2}$. The slices were rinsed with ice-cold modified Hanks' solution to remove col- lagenase. Each segment of the acini and granular convoluted tubules was dissected out with needles under a stereomicroscope. and each dissociated segment was collected in a siliconized capillary tube (Drummond Microcaps, $50 \mu l$ ).

SDS-polyacrylamide micro-disc electrophoresis: Each segment was dissolved in an equal volume of $6 \%(\mathrm{w} / \mathrm{V})$ sodium dodecyl sulphate (SDS) solution which contained $10 \% 2$-mercaptoethanol and then heated at $90^{\circ} \mathrm{C}$ for $3 \mathrm{~min}$. The protein content of each of the samples was determined by the method of Lowry et al. (20) with bovine serum albumin as the standard. One $\mu l$ of each sample, containing $1 \%(\mathrm{~W} / \mathrm{V})$ SDS, $5 \% 2$ mercaptoethanol and $20 \%$ glycerol, was applied to the top of a $4-40 \%$ continuous gradient polyacrylamide disc gel, in a $10 \mu !$ capillary tube, as described by Rüchel et al. (21). Electrophoresis was performed at room temperature at $60 \mathrm{~V}$ for $60 \mathrm{~min}$ in $50 \mathrm{mM}$ Trisglycine buffer $(\mathrm{pH} 8.4)$ in $0.1 \%$ SDS. The apparent molecular weights of the glycoproteins detected on the densitometric scan were estimated from the relative positions of myosin. $\beta$-galactosidase, phosphorylase b. albumin, ovalbumin. carbonic anhydrase, trypsin inhibitor and $\alpha$-lactalbumin, which were used as molecular weight markers. Gels were stained either with $0.2 \%$ Coomassie Brilliant Blue R-250 for protein or with periodic-Schiff's reagent (PAS) for glycoprotein, and then destained in 7\% acetic acid. The patterns of glycoproteins and proteins on the gels were recorded photographically and by spectrophotometric traces of the gels made with a Joyce-Loebl 3CS microdensitometer at a wave length of $595 \mathrm{~nm}$, for gels stained with Coomassie Blue, and at $550 \mathrm{~nm}$, for those stained with PAS.

Drugs: Drugs used were dobutamine hydrochloride (Shionogi Pharmaceutical Co., Osaka, Japan), terbutaline sulphate and metoprolol tartrate (Fujisawa Pharmaceutical Co., Osaka, Japan) and $\mathrm{ICl}-118551$ hydrochloride (ICl Pharmaceutical Division, Town, England).

Statistical analysis: Data are presented as the mean $\pm S$.E. of data from 6 rats. The statistical significance of differences was assessed by Student's $t$-test. 


\section{Results}

Secretory response of fluid from submandibular glands: Patterns of secretion of saliva elicited by dobutamine and terbutaline from the submandibular gland were similar when these drugs were administered alone. but differed when rats were also treated with antagonists. The salivary flow rates reached a maximal level 5-10 min after administration of either dobutamine or terbutaline at each dose tested (5, 10, 20 and $40 \mathrm{mg} / \mathrm{kg}$ ) and decreased gradually thereafter. The flow rate measured $30 \mathrm{~min}$ after administration of dobutamine at doses of $5,10,20$ and $40 \mathrm{mg} /$ $\mathrm{kg}$ decreased by $75.7,62.6,46.4$ and $39.4 \%$ from the maximum levels, whereas the flow rate $30 \mathrm{~min}$ after administration of terbutaline decreased by $47.2,39.1,47.2$ and $49.1 \%$, respectively (Fig. 1). However, when metoprolol was injected prior to administration of dobutamine at a dose of $40 \mathrm{mg} / \mathrm{kg}$, the salivary flow rates reached maximal levels after $5-10 \mathrm{~min}$ with a dose of $0.2 \mathrm{mg} / \mathrm{kg}$ of metoprolol and after 15-20 min with a dose of $1.0 \mathrm{mg} / \mathrm{kg}$. With a dose of $5 \mathrm{mg} / \mathrm{kg}$ of $\mathrm{me}$ toprolol. no maximum value was reached (Fig. 2A). When ICl-118551 was administered prior to dobutamine, flow rates reached maxi- mum values after $5-10 \mathrm{~min}$, as did those observed after administration of dobutamine alone (Fig. 2A). In contrast to these results. the time required to reach the maximum flow rate after administration of terbutaline was not changed by pretreatment with either metoprolol or $\mathrm{ICl}-118551$ at the above doses (Fig. 2B). Total volumes of saliva secreted from the submandibular glands during the 30 min which followed administration of either dobutamine or terbutaline increased in a dosedependent manner, and the volume of saliva elicited by dobutamine at doses of $10-40 \mathrm{mg} /$ $\mathrm{kg}$ were significantly higher than those elicited by terbutaline, as shown by the ED50 value, which was $8.7 \mathrm{mg} / \mathrm{kg}$ for dobutamine and $5.9 \mathrm{mg} / \mathrm{kg}$ for terbutaline (Fig. 3). The volumes of saliva elicited in response to either dobutamine or terbutaline at a dose of $40 \mathrm{mg} /$ $\mathrm{kg}$ were $39.82 \pm 2.60$ and $21.15 \pm 0.80 \mu / / 100$ $\mathrm{mg}$ wet weight gland $/ 30 \mathrm{~min}$, respectively. After pretreatment with each antagonist at doses of $0.2,1.0$ and $5.0 \mathrm{mg} / \mathrm{kg}$. the volumes of saliva elicited by dobutamine respectively decreased by $52.1,56.6$ and $87.0 \%$ with metoprolol and by $23.3,29.1$ and $35.6 \%$ with $\mathrm{ICl}-118551$; and the volume of saliva elicited by terbutaline respectively decreased by 40.6 . 52.4 and $86.3 \%$ with metoprolol and by 22.9 .

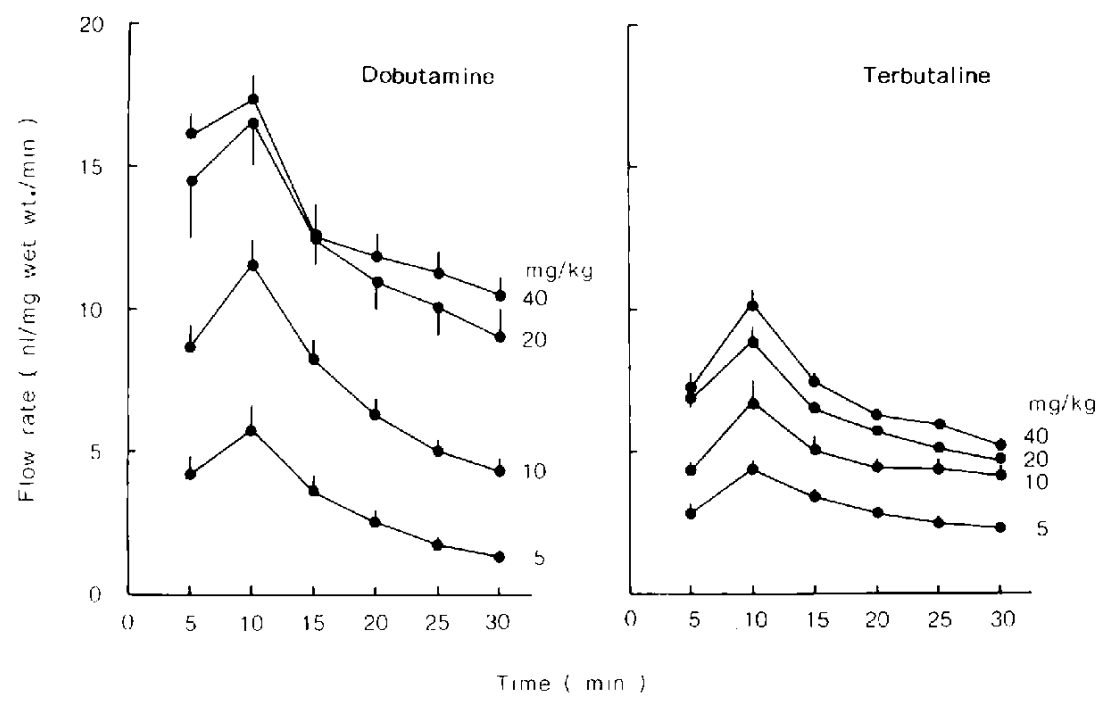

Fig. 1. A comparison of flow rates of saliva elicited from rat submandibular glands by i.p. administration of dobutamine or terbutaline at different doses. Each point represents the mean $\pm S$. E. of results from six animals. 
A
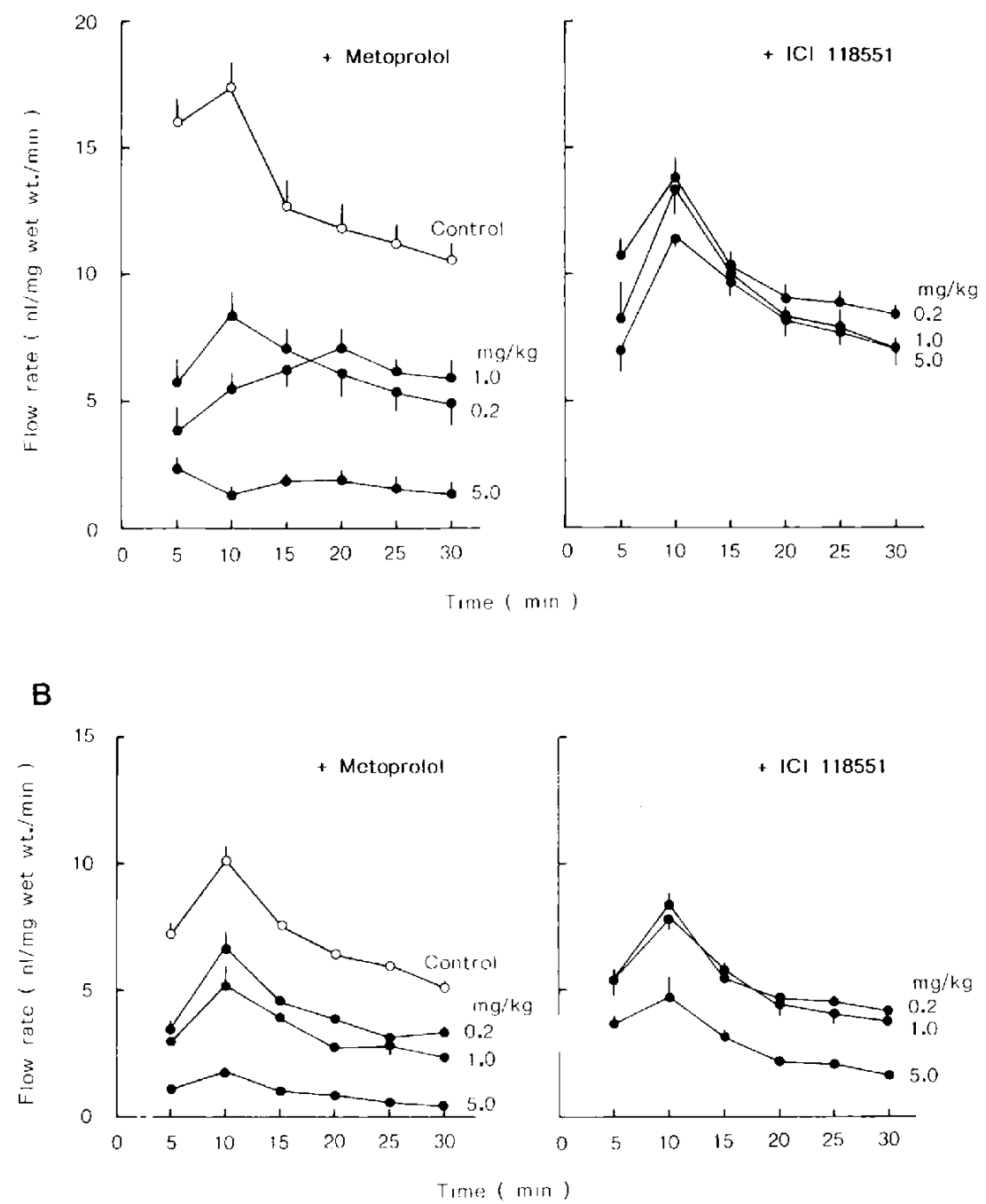

Fig. 2. Effects of pretreatment with either metoprolol or $\mathrm{ICl}-118551$ on the flow rates of saliva elicited from rat submandibular glands by administration of dobutamine (A) and terbutaline (B). Each antagonist was injected i.v. at a dose of 0.2 .1 .0 and $5.0 \mathrm{mg} / \mathrm{kg} .30 \mathrm{~min}$ prior to i.p. administration of each agonist at a dose of $40 \mathrm{mg} / \mathrm{kg}$. Each value represents the mean $\pm S$.E. of results from six animals.

29.4 and $59.2 \%$ with $\mathrm{ICl}-118551$ (data not shown)

Concentration and total amounts of protein in saliva secreted from the submandibular gland: The concentration of protein in saliva secreted from the submandibular gland during the 30 min which followed the administration of dobutamine increased in a dose-dependent manner, whereas with terbutaline, the concentration of protein showed a tendency to decrease with increasing doses of the drug. However, the concentrations of protein in saliva evoked by dobutamine were significantly lower than those evoked by terbutaline, at the doses of 5,10 and $20 \mathrm{mg} / \mathrm{kg}$. but not at $40 \mathrm{mg} / \mathrm{kg}$. In addition, the total amounts of protein secreted from the submandibular glands in response to either dobutamine or terbutaline increased progressively with increasing doses, with an 
especially sharp increase at doses from 10 to $20 \mathrm{mg} / \mathrm{kg}$ of dobutamine. However, the amounts of protein in saliva evoked by dobutamine at the dose of $5 \mathrm{mg} / \mathrm{kg}$ were significantly lower than those in saliva evoked by terbutaline (Table 1). When doses of $40 \mathrm{mg} /$ $\mathrm{kg}$ of dobutamine were administered after pretreatment with metoprolol or $1 \mathrm{Cl}-118551$

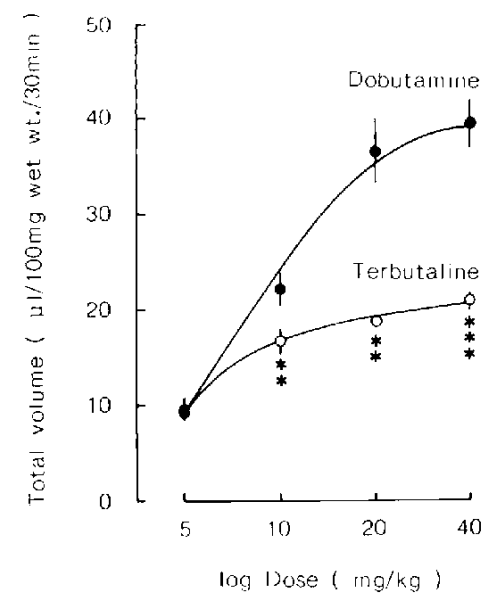

Fig. 3. Dose-resporise curve for the volume of saliva elicited from rat submandibular gland by i.p. administration of dobutamine or terbutaline. Total volume is represented as $\mu$ of saliva secreted per $100 \mathrm{mg}$ wet weight of the submandibular gland for the 30 min period which followed i.p. administration of dobutamine or terbutaline. Each point represents the mean $\pm S$.E. of results from six animals. ** and *** indicate a significant difference from the results with dobutamine at $P<0.01$ and $P<0.001$, respectively. at doses of $0.2,1.0$ and $5.0 \mathrm{mg} / \mathrm{kg}$ (i.v.), the concentration of protein in saliva evoked by dobutamine decreased as the doses of metoprolol increased, but was not changed significantly by pretreatment with $1 \mathrm{Cl}-118551$. The amount of protein was decreased by 44.2, 60.2 and $91.0 \%$ by pretreatment with metoprolol at the respective doses and by $19.5,38.3$ and $38.3 \%$ by pretreatment of $\mathrm{ICl}$ 118551 at the respective doses (Table 2A). When terbutaline was administered at a dose of $40 \mathrm{mg} / \mathrm{kg}$, the amounts of protein decreased by $14.8,33.1$ and $78.2 \%$ after pretreatment with metoprolol at doses of 0.2 .1 .0 and $5.0 \mathrm{mg} / \mathrm{kg}$, respectively and by 9.5 and $49.0 \%$ after pretreatment with $\mathrm{ICl}-118551$ at doses of 1.0 and $5.0 \mathrm{mg} / \mathrm{kg}$. respectively (Table 2B).

Electrophoretic profiles of the glycoproteins and proteins: The typical electrophoretic patterns of glycoproteins and proteins in the submandibular saliva elicited by i.p. administration of either dobutamine or terbutaline at a dose of $40 \mathrm{mg} / \mathrm{kg}$ are shown in Fig. 4. The patterns of glycoproteins and proteins did not differ significantly between dobutamineevoked and terbutaline-evoked saliva. Furthermore, the patterns obtained at lower doses of either dobutamine or terbutaline (at 5. 10 and $20 \mathrm{mg} / \mathrm{kg}$ ) were similar to those obtained at a dose of $40 \mathrm{mg} / \mathrm{kg}$ (data not shown). The glycoprotein profiles of dobutamine-and terbutaline-evoked saliva showed a heavily stained band I and two minor bands.

Table 1. A comparison of concentrations and total amounts of protein in saliva elicited from rat submandibular glands during the $30 \mathrm{~min}$ after i.p. administration of either dobutamine or terbutaline at different doses

\begin{tabular}{cccc}
\hline \multirow{2}{*}{ Drug } & $\begin{array}{c}\text { Dose } \\
(\mathrm{mg} / \mathrm{kg})\end{array}$ & $\begin{array}{c}\text { Protein conc. } \\
(\mathrm{mg} / \mathrm{ml})\end{array}$ & $\begin{array}{c}\text { Protein secreted } \\
(\mathrm{mg} / 100 \mathrm{mg} \text { wet } \\
\mathrm{wt} . / 30 \mathrm{~min})\end{array}$ \\
Dobutamine & 5 & $23.86 \pm 0.77$ & $0.23 \pm 0.04$ \\
& 10 & $30.35 \pm 1.50$ & $0.67 \pm 0.06$ \\
& 20 & $34.95 \pm 1.53$ & $1.27 \pm 0.14$ \\
Terbutaline & 40 & $38.34 \pm 2.43$ & $1.51 \pm 0.08$ \\
& 5 & $46.90 \pm 3.11^{* * *}$ & $0.42 \pm 0.02^{* *}$ \\
& 10 & $42.78 \pm 2.55^{* *}$ & $0.64 \pm 0.09^{* *}$ \\
& 20 & $42.94 \pm 1.71^{* *}$ & $0.81 \pm 0.04^{*}$ \\
& 40 & $41.52 \pm 1.41$ & $0.87 \pm 0.02^{* * *}$
\end{tabular}

Each value represents the mean \pm S.E. of results from six animals. "* and *** indicate a significant difference from the results with dobutamine at $P<0.01$ and $P<0.001$, respectively. 
Table 2. Effects of pretreatment with either metoprolol or $\mathrm{iCl}-118551$ on the concentrations and total amounts of protein in saliva elicited from rat submandibular glands by dobutamine (A) and by terbutaline (B)

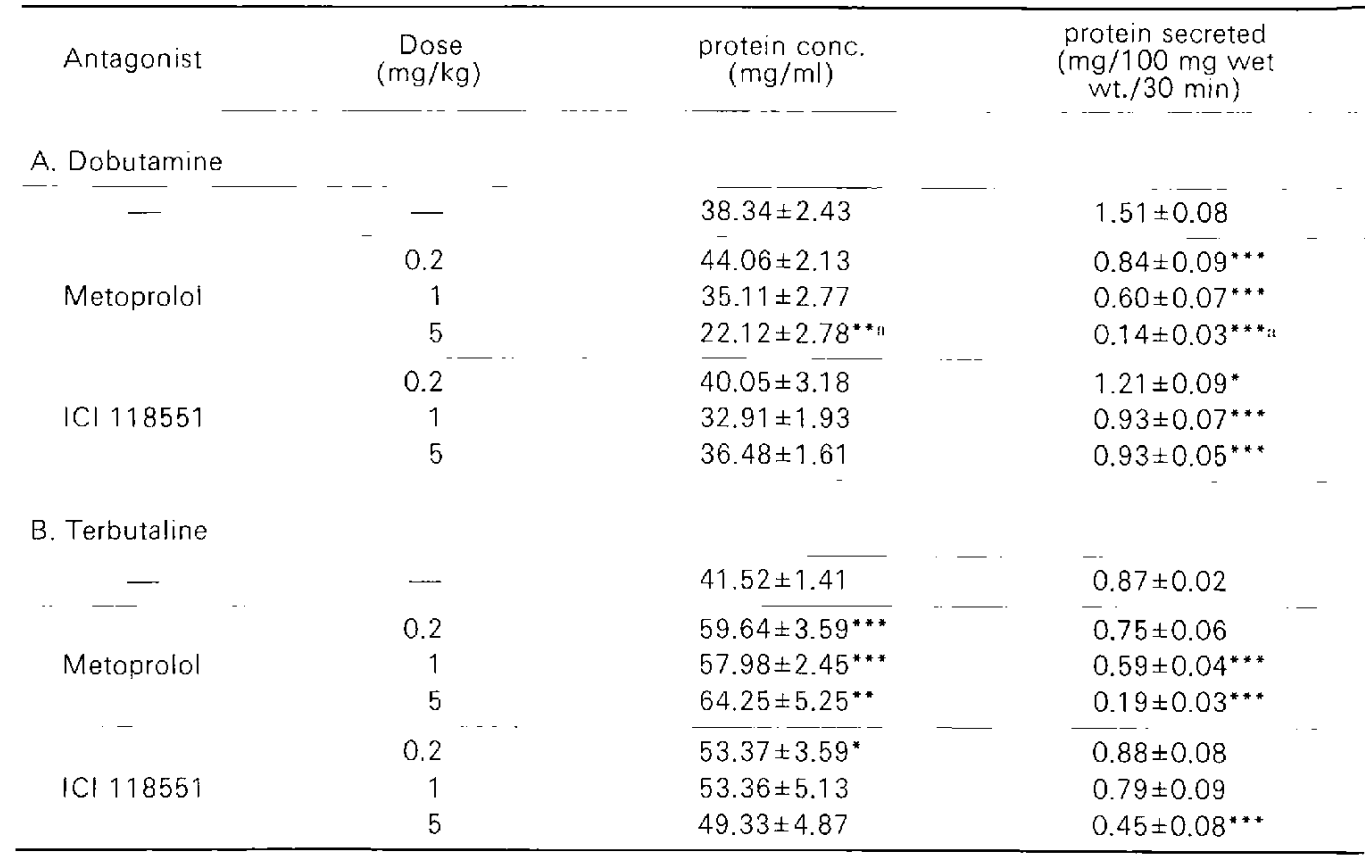

Each antagonist was injected i.v. at a dose of $0.2,1.0$ and $5.0 \mathrm{mg} / \mathrm{kg}, 30 \mathrm{~min}$ prior to i.p. administration of dobutamine and terbutaline at a dose of $40 \mathrm{mg} / \mathrm{kg}$. Each value represents the mean $\pm S$. E. of results from six animals. five animals for ("). * ** and *** indicate a significant difference from the results with control at $P<0.05, P<0.01$ and $P<0.001$, respectively.

$I I I$ and IV. The pattern of glycoproteins from secretory segments isolated from the submandibular gland of the normal rat showed that the acinar segments contain one major band, band (I), and three minor bands, bands (II). (III) and (IV). whereas the granular tubule segments contain one major band. band (III), and two minor bands, band (I) and band (II), as reported previously (14) (data not shown). When dobutamine- or terbutaline-evoked saliva were co-electrophoresed with samples of the acinus or samples of the granular tubules, the main bands I and IV of the saliva were electrophoretically identical with the main bands (I) and
(IV) in the acinar samples, whereas band III was electrophoretically identical to the major band (III) in the granular tubules. In the figure, the PAS-positive bands are indicated by an arrow above the corresponding $\mathrm{Co}$ omassie brilliant blue-stained bands. The protein band corresponding to glycoprotein band I is hardly stained with Coomassie blue. whereas the proteins which correspond to glycoprotein bands III and IV were strongly stained (Fig. 4B). The apparent molecular weights of proteins in bands I, III and IV are $130 \mathrm{~K}, 31 \mathrm{~K}$ and $21.5 \mathrm{~K}$ daltons, as reported previously (14). When rats were pretreated with metoprolol at a dose of $5 \mathrm{mg} / \mathrm{kg}$. dobu-

Fig. 4. Typical densitometric scans of glycoprotein (A) and proteins (B) of submandibular saliva. Metoprolol at a dose of $5 \mathrm{mg} / \mathrm{kg}$ was injected i.v. $30 \mathrm{~min}$ prior to i.p. administration of dobutamine or terbutaline at a dose of $40 \mathrm{mg} / \mathrm{kg}$. Samples containing 0.5 and $0.25 \mu \mathrm{g}$ of protein were applied to gels. After electrophoresis, gels were stained with PAS or Coomassie Blue. Electrophoresis was performed as described in Materials and Methods. PAS-positive bands are indicated by an arrow above the corresponding Coomassie Blue-stained band 
A

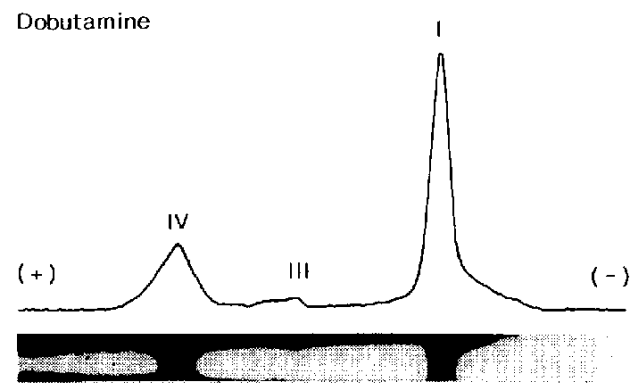

Dobutamine

Metoprolol

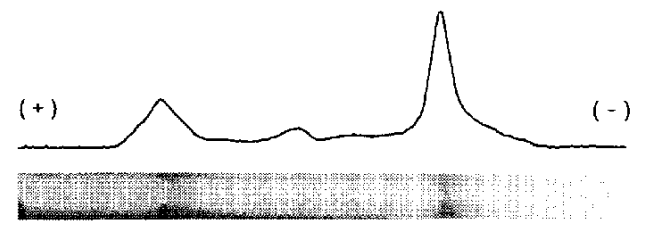

B

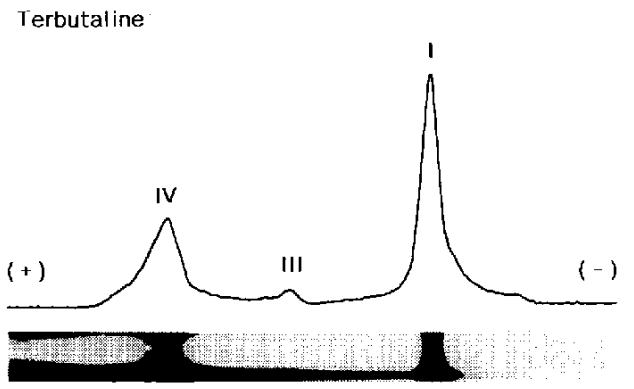

Terbutaline

Metoprolol

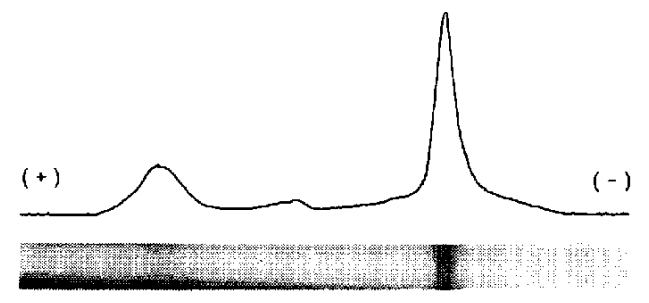

Dobutamine

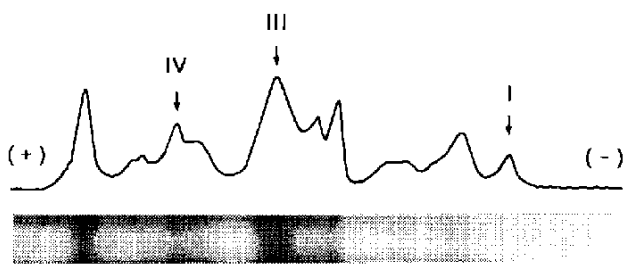

Dobutamine

Metoprolol
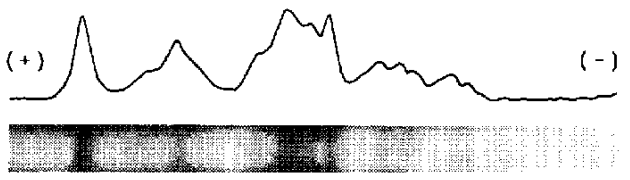

Terbutaline

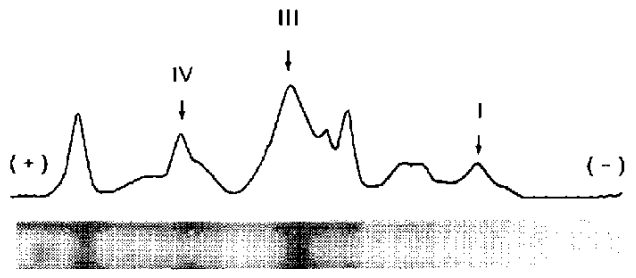

Terbutaline

Metoprolol

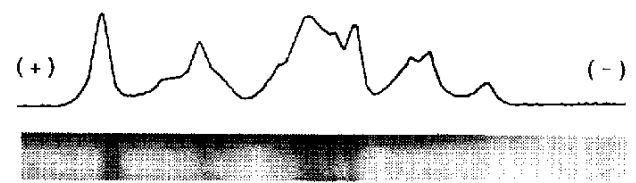


tamine at a dose of $40 \mathrm{mg} / \mathrm{kg}$ decreased the intensity of glycoprotein bands I and IV (Fig. $4 A$ ), but such a result was not observed with metoprolol at the doses of 0.2 and $1.0 \mathrm{mg} / \mathrm{kg}$ (data not shown). When $\mathrm{ICl}-118551$ was administered prior to dobutamine, the patterns were similar to those observed after treatment with dobutamine alone (data not shown). On the other hand, the patterns of terbutaline-evoked saliva were not altered by pretreatment with metoprolol (Fig. 4) or $\mathrm{ICl}$ 118551 (data not shown). Furthermore. electrophoretic patterns of proteins stained with Coomassie blue in dobutamine- and terbutaline-evoked saliva did not change after pretreatment with metoprolol (Fig. 4 ) or $\mathrm{ICl}$ 118551 (data not shown).

\section{Discussion}

In the present study, the ED50 value with respect to secretion of saliva from the submandibular gland of rats was $8.7 \mathrm{mg} / \mathrm{kg}$ for dobutamine and $5.9 \mathrm{mg} / \mathrm{kg}$ for terbutaline. A difference between dobutamine and terbutaline has also been observed in the secretory potency for the salivation from the submandibular gland of rats (4). On the other hand, the concentration of protein in terbutaline-evoked saliva was significantly higher than that of dobutamine-evaked saliva when drugs were administered at doses of 5, 10 and $20 \mathrm{mg} / \mathrm{kg}$, respectively, but no significant difference was found at the dose of $40 \mathrm{mg} / \mathrm{kg}$ (Table 1). In fact, terbutaline evoked a small volume of saliva rich in protein. Thus, these results suggest that terbutaline administered at small doses stimulates $\beta_{2}$-receptors, as generally recognized, but at large doses, it may stimulate both $\beta_{1}$-receptors and $\beta_{2}$-receptors.

To estimate receptors mediating these reactions, three doses of metoprolol, which has been characterized as a selective $\hat{\beta}_{1}$ antagonist (22), and $\mathrm{ICl}-118551$, which has been characterized as a selective $\beta_{2}$-antagonist $(23.24)$, were applied before $40 \mathrm{mg} /$ $\mathrm{kg}$ of dobutamine or terbutaline was administered. Pretreatment with metoprolol inhibited secretion of fluid (Fig. 2A) and protein (Table 2A) induced by dobutamine in a dosedependent manner. On the other hand, the inhibitory effect of $1 \mathrm{Cl}-118551$ was slight and considerably lower than that of me- toprolol (Fig. 2A, Table 2A). This result may be attributed to a low level of activity toward $\beta_{2}$-adrenoceptors of dobutamine, which was suggested by observations of the relaxation of vascular smooth muscle $(25-27)$ and the adenylate cyclase or GTPase activity in erythrocyte membranes of the turkey and frog (28). Furthermore, pretreatment with metoprolol more strongly inhibited the secretion of fluid and protein induced by terbutaline than pretreatment with $\mathrm{ICl}-118551$ (Fig. 2B. Table 2B). The present data suggests that terbutaline probably activates $\beta_{1}$-adrenoceptors, rather than $\beta_{2}$-adrenoceptors. This conclusion is consistent with the reports that secretion of either fluid or calcium from submandibular gland $(3,4)$ and enlargement of the parotid and submandibular gland (26) induced by administration of terbutaline were inhibited more effectively by the selective $\beta_{1}$ antagonist atenolol than the selective $\beta_{2}$ antagonist butoxamine.

On the other hand, the concentration of protein in dobutamine evoked saliva were reduced in a dose-dependent manner by pretreatment with metoprolol, but were not changed significantly by pretreatment with ICI-118551 (Table 2A). In contrast, the concentrations of protein in terbutaline-evoked saliva were increased more significantly by pretreatment with metoprolol than by pretreatment of $\mathrm{Cl}-118551$ (Table 2B). This increase may be produced by mediation of $\beta_{2}$ receptors because of a blockade of $\beta_{1}$ receptors. Therefore, secretion of saliva rich in protein may be caused by activation of $\beta_{2}$ receptors rather than $\beta_{\uparrow}$-receptors.

The present data thus show that $\beta$ adrenoceptor mediated secretion of saliva and protein from rat submandibular glands would be mainly due to receptors of the $\beta_{1}$ subtype. This speculation is consistent with the results on radioligand binding $(29,30)$, which indicate that the $\beta$-adrenoceptors of the rat submandibular glands are predominantly of the $\beta_{1}$-type. However, our data suggests that the possibility that $\beta_{2}$-receptors may exist in the submandibular gland cannot be negleted, since $\mathrm{ICl}-118551$ has partially inhibitory effects on terbutaline. It is not known whether secretion of saliva and protein induced by terbutaline at small doses is 
caused only by activation of $\beta_{2}$-receptors.

Moreover, in this study, the action of dobutamine and terbutaline on the secretory cells of the submandibular gland was confirmed by estimations of marker species of glycoproteins, which are contained in the secretory segments and detected in drugevoked saliva. The administration of dobutamine or terbutaline at doses of 5, 10, 20 and $40 \mathrm{mg} / \mathrm{kg}$ elicited the secretion of the glycoproteins designated as bands I and IV. which are characteristically contained in acinar cells (Fig. 4). However, the intensities of both bands were considerably higher than those found by administration of choline esters (31): these phenomena indicate that both dobutamine and terbutaline acts on acinar cells more strongly than choline esters. On the other hand, when rats were pretreated with metoprolol at a dose of $5 \mathrm{mg} / \mathrm{kg}$. dobutamine at a dose of $40 \mathrm{mg} / \mathrm{kg}$ produced a decrease in intensity of glycoprotein bands I and IV. although such a change was not observed after pretreatment with $\mid \mathrm{Cl}-118551$ (Fig. 4). This decrease in band I may be caused by a blockade of the $\beta_{1}$-adrenoceptors of the acinus. On the other hand, when administered with a prior dose of $5 \mathrm{mg} / \mathrm{kg}$ of $\mathrm{ICl}-118551$ or metoprolol. terbutaline, at a dose of $40 \mathrm{mg} / \mathrm{kg}$. generated profiles of glycoproteins which were similar to those found in saliva evoked by terbutaline alone. Abe et al. (3) have shown that the electrophoretic patterns of proteins in saliva elicited from submandibular glands of rats by terbutaline were similar to those observed after treatment with isoproterenol, and these patterns were not altered by pretreatment with metoprolol or $\mathrm{ICl}-118551$. Our findings are in agreement with these results: that is, the electrophoretic patterns were similar in dobutamine- and terbutaline-evoked saliva, and the patterns were not altered by pretreatment with metoprolol or $1 \mathrm{Cl}-118551$.

In conclusion, the present study showed that the submandibular gland of the rat contains both $\beta_{1}$ - and $\beta_{2}$-adrenoceptors and that the $\beta$-receptors, that mediate secretion of glycoprotein from the acinus and fluid from the gland are mainly of the $\beta_{1}$-subtype.

Acknowledgments: This study was supported in part by a Grant-in-Aid for Scientific Research (No.
60480404) from the Ministry of Education. Science and Culture of Japan. We express our thanks to the Fujisawa Pharmaceutical Co., Ltd., for the gift of terbutaline and metoprolol and to the Pharmaceutical Division of $\mathrm{ICl}$ for the gift of $\mathrm{ICl}-118551$.

\section{References}

1 Lands, A.M., Arnold, A., McAuliff, J.P., Luduena, F.P. and Brown, T.G., Jr.: Differentiation of receptor systems activated by sympathomimetic amines. Nature 214, 597-598 (1967)

2 Lands, A.M., Luduena, F.P. and Buzzo, H.J.: Differentiation of receptors responsive to isoproterenol. Life Sci. 6, 2241-2249 (1967)

3 Abe, K., Inoue, H. and Yokota, Y.: Effects of the selective $\beta_{2}$-adrenergic agonists, procaterole and terbutaline, on protein secretion by rat submandibular glands. J. Dent. Res. 64, 866890 (1985)

4 Schneyer, C.A., Yu, J.H. and Jirakulsomchok, D.: Modification of dobutamine- and terbutalineinduced calcium and fluid secretion from rat salivary glands by atenolol and butoxamine. J. Auton. Nerv. Syst. 13, 275-285 (1985)

5 Ekström, J.: Salivary secretion evoked by H8O/ 62. ( \pm ) - 1 - (4 - hydroxyphenoxy) - 3 - isopropylamino-2-propranol, a new $\beta_{1}$-selective adrenoceptor agonist. Acta Pharmacol. Toxicol. 45, 325-328 (1979)

6 Thulin, A.: On the $\beta$-adrenergic receptors ir salivary glands of rat and dogs. Experientia 28 , 420-421 (1972)

7 Brenner, G.E. and Wulf, R.G.: Adrenergic beta receptors mediating submandibular salivary gland hypertrophy in the rat. J. Pharmacol. Exp. Ther. 211, 502-508 (1979)

8 Schneyer, C.A.: Growth of rat salivary glands after terbutaline or dobutamine. J. Oral Pathol. 15, 66-70 (1986)

9 Schneyer, C.A. and Cheung, H.: Ca-ATPase activity in salivary glands of rats treated with reserpine, isoproterenol, terbutaine or dobutamine. Arch. Oral Biol. 32, 445-447 (1987)

10 Carlsöö, B., Danielsson, Å., Henriksson, R. and Idahl, L.-A.: Dissociation of $\beta$-adrenoceptorinduced effects on amylase secretion and cyclic adenosine $3^{\prime}, 5^{\prime}$-monophosphate accumulation. Br. J. Pharmacol. 75, 633-638 (1982)

11 Henriksson, $R: \beta_{1}$ - and $\beta_{2}$-adrenoceptor agonists have different effects on rat parotid acinar cells. Am. J. Physiol. 242, G481-G485 (1982)

12 Carlsöö, B., Danielsson, $\AA$. and Henriksson, R.: $\beta_{1}$ - and $\beta_{2}$-adrenoceptor-mediated secretion of amylase from incubated rat parotid gland. Acta 
Physiol. Scand. 120, 429-435 (1984)

13 Suzuki, $Y$. and Ohshika, $H_{\text {: }} \beta_{1}$-Adrenoceptormediated amylase release and cyclic AMP accumulation in rat parotid gland tissue. Japan. J. Pharmacol. 37, 212-214 (1985)

14 Masuhara, T. and Iwabuchi, Y.: Micro-discelectrophoretic study on glycoproteins of parenchymal components dissociated from rat submandibular gland. Japan. J. Oral Biol. 25, $1177-$ $1180(1983)$

15 Iwabuchi, Y., Aoki, C. and Masuhara, T.: Effects of adrenergic agents on glycoprotein secretion from acini and granular convoluted tubules of the rat submandibular gland. Japan. J. Oral Biol. 27, 741-745 (1985)

16 Masuhara, T. and Iwabuchi, Y.: Characterization of glycoproteins in submandibular acinus and saliva of rats elicited by pilocarpine. Japan. J. Oral Biol. 26, 280-283 (1984)

17 Iwabuchi, Y., Aoki, C. and Masuhara, T.: Effects of substance $P$ on glycoprotein secretion from acinar cells of the rat submandibular gland. Japan. J. Pharmacol. 42, 453-456 (1986)

18 Iwabuchi, Y.. Aoki, C. and Masuhara, T.: Secretory pattern of characteristic glycoprotein species from segments of the rat submandibular gland following methoxamine stimulation. Japan. J. Oral Biol. 27, 1267-1271 (1984)

19 Iwabuchi, Y., Aoki, C. and Masuhara, T.: Effects of adrenergic antagonists on glycoprotein secretion from granular convoluted tubules of the rat submandibular gland induced by methoxamine. Japan. J. Oral Biol. 28, 761-765 (1986)

20 Lowry, O.H., Rosebrough, N.J., Farr, A.L. and Randall, R.J.: Protein measurement with the Folin phenol reagent. J. Biol. Chem. 193, 265275 (1951)

21 Rüchel, R., Mesecke, S., Wolfrum, D.I. and Neuhoff, V.: Mikroelektrophorese an Kontinuierlichen polyacrylamide Gradiented Gelen. I. Herstellung und Eigenschaften von Gelgradienten in Kapiliaren; ihre Anwendung zur Proteinfraktionierung und Molgewichts-bestimmung. Hoppe Seylers Z. Physiol. Chem. 354, 13511368 (1973)
22 Åblad, B., Brog, K.O., Carlsson, E., Ek, L., Johnsson, G., Malmfors, T. and Regardh, C.G.: A survey of the pharmacological properties of metoprolol in animals and man. Acta Pharmacol. Toxicol. 36. Supp. V, 7-23 (1975)

23 Bilski, A., Dorries, S., Fitzgerald, J.D., Jessup, R., Tucker, H. and Wale, J.: $\mid \mathrm{Cl} 118,551$, a potent $\beta_{2}$-adrenoceptor antagonist. Br. J. Pharmacol. 69, 292-293 (1980)

24 O'Donnell, R.S. and Wanstall, J.C.: Evidence that ICI 118,551 is a potent highly beta ${ }_{2}$-selective adrenoceptor antagonist and can be used to characterize beta-adrenoceptor populations in tissues. Life Sci. 27, 671-677 (1980)

25 Tuttle, R.R. and Mills, J.: Dobutamine: development of a new catecholamine to selectively increase cardiac contractility. Circ. Res. 36, $185-196$ (1975)

26 Sonnenblick. E.H., Frishman. W.H. and LeJemtel, T.H.: Dobutamine: A new synthetic cardioactive sympathetic amine. N. Engl. J. Med. 300, 17-22 (1979)

27 Robie, N.W., Nutter, D.D., Moody, C, and McNay, L.J.: In vitro analysis of adrenergic receptor activity of dobutamine. Circ. Res. 34, 633-671 (1974)

28 Pike, L.J. and Lefkowitz, R.J.: Activation and desensitization of $\beta$-adrenergic receptor-coupled GTPase and adenylate cyclase of frog and turkey erythrocyte membranes. J. Biol. Chem. 225, 6860-6867 (1980)

29 Bylund, D.B., Forte, L.R., Morgan, D.W. and Martinez, J.R.: Effects of chronic reserpine administration on beta adrenergic receptors. adenylate cyclase and phosphodiesterase of the rat submandibular gland. J. Pharmacol. Exp. Ther. 218, 134-141 (1981)

30 Pointon, S.E. and Banerjee, S.P.: Alpha- and beta-adrenergic receptors of the rat sativary gland. Biochim. Biophys. Acta 584, 231-241 (1979)

31 Aoki, C., Iwabuchi, Y. and Masuhara, T.: The effect of cholinergic drugs on glycoprotein secretion from the functional segments of rat submandibular glands. Japan. J. Pharmacol. 40, Supp. 184P (1986) 